\title{
THE RELATIONSHIP AMONG SOVEREIGN CREDIT RISK PREMIUM, SOVEREIGN BONDS AND CURRENCY RATES IN FRAGILE THREE COUNTRIES
}

DOI: 10.17261/Pressacademia.2020.1302

JBEF- V.9-ISS.3-2020(7)-p.262-273

Tugba Akin¹, Emre Isikli²

${ }^{1}$ Aydin Adnan Menderes University, Faculty of Aydin Economics, Department of Econometrics, Aydin, Turkey tugba.akin@adu.edu.tr, ORCID :0000-0002-1132-388X

${ }^{2}$ Aydin Adnan Menderes University, Buharkent Vocational College, Department of Alternative Energy, Buharkent, Aydin. Turkey. e.isikli@adu.edu.tr, ORCID: 0000-0003-4148-7655

Date Received: May 24, 2020

Date Accepted: September 8, 2020

To cite this document

Akın, T., Isikli, E., (2020). The relationship among sovereign credit risk premium, sovereign bonds and currency rates in fragile three countries. Journal of Business, Economics and Finance (JBEF), V.7(3), p.262-273.

Permanent link to this document: http://doi.org/10.17261/Pressacademia.2020.1302

Copyright: Published by PressAcademia and limited licensed re-use rights only.

\section{ABSTRACT}

Purpose- For developing countries that are highly dependent on foreign investment in terms of saving gap funding, risk assessment tools are crucially important. Under the evolving circumstance of flow of international funds along the last decade, this study aims to investigate into causality relationship among sovereign credit default swap premiums, interest and currency rates of "Fragile Three" Countries of Brazil, South Africa and Turkey through new generation econometric methods for the period of 2007M2-2017M1.

Methodology-To that end, stationarity, co-integration and causality relationships were analysed by means of Kapetanios's (2005) multi-structural fractural unit root test, Johansen Cointegration Test (1990) and Toda-Yamamoto (1995) test (TY), respectively.

Findings- Our findings suggest that these variables of $F 3$ countries are influenced substantially from each other.

Conclusion- The necessary economic policies should be developed to ensure permanent stability at exchange rate and interest rate levels. In order to ensure these countries to maintain financial stability, economic, political and social reforms are required to minimize country risks and to decrease dependency on foreign capital.

Keywords: Sovereign credit default swap premiums, sovereign bond interest rates, foreign currency, fragile three. JEL Codes: G15, F31

\section{INTRODUCTION}

Fluctuations experienced in the world economy along the last decade have intensively influenced developing countries owing to their fragile macroeconomic indicators and strong dependency on foreign funds. The onset of the economic crisis in developed countries launched by the mortgage crisis in 2008 influenced developing countries as well. Vast amount of monetary resource was injected into the developed markets for strengthening their financial system (Breuer and Sauter, 2013). Federal Reserve (FED) followed cheap money policy and decreased interest rates from $5 \%$ to $0.25 \%$ gradually. This situation especially enhanced attractiveness of developing countries highly dependent on foreign funds and offering high interest rates for global investors. While developing countries enjoyed these fund inflows, however, they were exposed associated risks.

Similar to the oceanic tidal behaviour, these funds, which flooded into emerging markets afterwards of mortgage crisis, then started to migrate back to their home, developed countries, after FED's statement on rising interest rates slowly by reducing government bond purchase on May 2013. Accordingly, emerging markets faced with difficult position in terms of accessing current global funds. These economic developments resulted in fragility concept to come forward in the relevant literature. Financial ly fragile means that borrowers who perpetrate economic activity as entrepreneurs have inadequate resources for the realization of their production decisions (Bernanke and Gertler, 1990: 88). Accordingly, fragility levels of developing countries with hi gh dependency on global capital markets, measured by financial ranking institutions are considered important indicator for foreign 
investors (Bekkour et al., 2015). Financial markets measure fragility through various economic indicators. Recent reports published by financial institutions are closely followed by "international investors" with abundant saving, who are significantly y effective on flows of global funds. In this sense, countries with high dependency on foreign capital are monitored by prominent financial ranking institutions in terms of their macroeconomic indicators so that they could be classified on the basis of their individ ual risk exposure.

In the economy report published by Morgan Stanley in August 2013, countries' current account deficit to GDP rate s were analyzed and the countries were ranked with respect to their sensitivity to capital inflows. While India, Brazil, Indonesia, Turkey an d South Africa were referred as the most "fragile five" countries (Morgan Stanley, 2013), Turkey was addressed as the most fragile country in this list. As India and Indonesia have succeeded to gain a positive economic posture owing to their structural reforms, in the suggestion report published by the Bank of America Merrill Lynch in 2017, Turkey, Brazil and South Africa were assessed as the most risky three countries for investment and referred as "Fragile Three" (F3) (ETF Trends, 2017).

Financial markets take numbers of economic indicators into consideration in evaluation of individual country economies. The concept of the "Credit Default Swap" (CDS) was gifted the finance world by the JP Morgan in 1994 (Augustin et al., 2016). In terms of monitoring financial risks in the market, CDS premiums have been an alternative tool besides sovereign credit scores (Mora, 2006, p.9; Flannery et al., 2010, p.2095; Başarır and Keten, 2016). The CDS has been recognized as useful tool which differentiates the default risk of bond issuer party from other risks clearly in assessment and pricing of the credit risk (Whetten, et al., 2004). Thus, CDS has been preferred over other credit derivatives (Norden and Weber, 2009, p.530). In other words, sovereign CDS functioning as credit insurances directly effective on investment made on a portfolio (e.g. sovereign bonds) in a country. The greater the CDS premium (read as score) for a specific country, the higher the cost of foreign debt is (Fontana and Scheicher, 2010).

Economic and political stability is directly effective on country CDS premiums. One of the most significant risk factors for foreign investments is the status in which the investment would not find its nominal value. In theory, CDS premiums are required to be closely related with risky bond yield, in other words, the CDS premium has adverse effect on interest rates and the term spread (Duffee, 1999; Whetten el al., 2004). It's expected and empirically proved that when interest rates rise CDS spreads will be rise (Kargl, 2014). Additionally, the risk is comprised of the risk of interest rates as well as risk of exchange rates (Zh ang et al., 2009; Yang, et al., 2010). Accordingly, correlation and interaction are expected among sovereign CDS, currency rate and interest ra te. Whereas the global capital inflow is important for the developing countries highly dependent to foreign funds, the minimization of associated risk is important for investors as much. For this reason, countries like Brazil, South Africa, and Turkey were selected due to their high sensitivity to foreign capital inflows. An increase in the fragility of these countri es will also affect their exchange rates and interest rates, indirectly. As the relationship between country risk and exchange and interest rates have been investigated by numbers of researchers, the reported findings are varied in a wide spectrum due to the studied data frequency, country, time period, employed analysis method, and so on. In this sense, it would be appropriate to read and consider the re sults reported by various researchers according to their unique study conditions and perspectives. From the point of view reflected by the notable and similar studies in the literature, also summarized herein paper, as the financial risk perceived by foreign investors toward a certain country increase, this country's overall interest burden on its foreign bo rrowing tends to increase. CDS premiums needed to be paid in the exchange of investment in such country equities tend to increase as well.

This study aims to investigate into effects of government bond interest rate (BIR) and foreign exchange (FX, local cu rrency to USD) on CDS premiums in Brazil, South Africa, and Turkey referred as "Fragile Three" through using Johansen Cointegration test and Toda-Yamamoto (1995) causality test for the period of 2007M2-2017M1. In this study, the effect of increasing the fragility of concerned three countries to foreign capital inflows was tried to be revealed. It was expected that this study to draw the at tention of these countries to financial risks because the rise in interest and exchange rates may also increase the fina ncial risk perception toward these countries. After the relevant literature review presented in Section 2, study data and the methodology employed to identify the relationship between saving-investment gap and growth rate was presented in Section 3. Finally, empirical modeling framework and conclusion were included in Section 4 and 5, respectively. Countries with high dependency on foreign financing use interest rates to attract foreign capital inflow. However, this situation can adversely affect the risk perception of the country. To observe this effect, in this study, Brazil, South Africa, and Turkey were selected as samples because of their high economic vulnerability and dependence on foreign financing. At the same time, the relationship between CDS and BIR, FX was realized with using cointegration test different than the earlier empirical studies. In this regard, this study is expected to bring a nove I analysis perspective and to make a contribution to the literature and attract the attention of policymakers. 


\section{LITERATURE REVIEW}

The Credit Default Swap (CDS) premiums, one of the significant financial economy concepts associated with risk, has started to be utilized in the empirical context in the beginning of 2000s (Skinner and Townend, 2002) as an indicator reflecting perceived market risk toward equities from a certain country or a corporation. As the CDS premium concept refers overall CDS premiums required in the market, sovereign CDS concept denotes the ones issued on country equity.

The preliminary empirical study on CDS was conducted by Skinner and Townend (2002), in which five factors (risk-free rate, yield on the reference security, volatility, maturity and the exercise price) that could determine the value of CDSs were analyzed by using linear regression model for the period of 1997M9-1999M2 on non-Asian and Asian subsamples. Authors find these five variables as important estimators of CDS premium. Similarly, Chan-Lau and Kim (2004) investigated the correlation between equity prices, CDS and bond rates in emerging markets by means of cointegration analysis, Granger causality tests, and by the price discovery measures proposed by Hasbrouck (1995) and Gonzalo and Granger (1995, p.27) for the period of M3.2001 -M3.2003. Researchers report that the CDS and bond spreads are cointegrated in all countries with the exception of Mexico, the Philippines, and Turkey. The existence of the equilibrium price relationship between the CDS and bond markets provides evidence that arbitrage forces between CDS and bond spreads to converge in spite of the pressures arising from market frictions and other various technical factors. The Granger causality tests show causality between markets, a one-day horizon. The CDS is found as significant estimator of the price discovery process for most countries. For the longer horizon, price discovery occurs in both the CDS and bond markets. In some countries, it is evidenced that the bond market led the CDS market for longer horizons. In Braz il case, the CDS contributes into price estimation in the range of $1 \%$ to $78 \%$. Nevertheless, the Hasbrouck finds that Gonzalo and Granger statistics show for most of the countries that the CDS market has slight edge over the bond market for price estimati on.

On the other hand, Zhang, Yau and Fung (2009) studied the lead-lag relationship between the CDS market and the currency market based on the data covering M1.2004 to M2.2008 by accounting for daily currency rates of JPY, EUR, GBP and AUD to USD and currency rates of JPY, USD, GBP and AUD to EUR. Researchers report the significant Granger-causality effects flowing from changes in both the North American investment-grade (IG) and from high-yield (HY) CDS indices to changes in the JPY, EUR and AUD exchange rates in terms of the USD for the whole period and during the credit crisis of 2007 to 2008 . However, for the four currencies accounted in terms of the EUR, significant Granger-causality of the credit risk is found only with the AUD.

Norden and Weber (2009) report positive correlation between CDS spread and bond market based on a study employed Granger analysis. Although CDS is found effective on price discovery bond prices, it is more effective in stock markets.

Yang, Morley and Hudson (2010) analyzed the casual relationship between CDS premiums, risk-free interest rates and exchange rates by using VAR and VECM econometric models for the period of 2005-2009 for both the US and France. Researchers address bi-directional Granger causality between CDS premium and exchange rate in France and unidirecti onal Granger causality between CDS premium and exchange rate in the US. While researchers report negative correlation between CDS and foreign exchange for France, they report a positive correlation for the US.

In another recent study, O'Kane (2012) investigated the relationship between the Eurozone sovereign CDS premiums and the same sovereign bond markets by employing the Granger causality test for the period of Eurozone debt crisis in 2009-2011. The researcher finds both autocorrelation and cross-correlation between lagged values of changes in the CDS premium and the bond yield spread, with the greatest effect occurring at a lag of one day. The researcher also reports the dominant direction of information flow from CDS premiums to bonds for Greece, but from bonds to CDS for France and Italy, while Ireland and Portugal exhibited Granger causality in both directions.

Mora-Jensen (2013) analyzed the empirical relationship between sovereign CDS premiums and Yen/USD exchange rate for the period between early 2005 and 2010. The results indicate that in stable periods, there is no relation or Granger Causality effect from either the CDS premium to the exchange rate or vice versa. On the contrary, during the financial crises period, strong implications of information flow between the CDS spreads on to the exchange rate are observed. There are signals that Japanese CDS premiums have Granger causing effect on the Yen/USD exchange rate.

Covering the European Debt crisis period (2009-2012), Koy (2014) studied the relationship between the CDS Premium and Eurobond foreign countries including Germany, France, Italy, Spain, Portugal, Ireland, Turkey and Greece by unit root test and cointegration analysis. The author reports significant causality from CDS premiums to Eurobond premiums. Results concerning Turkey suggest that changes in CDS premiums lead changes in Eurobond premiums. 
Similarly, Sambalaibat (2014) studied the relationship between sovereign CDS and bond rates through regression model especial ly for the recent debt crisis in Europe based on the data covering the period of 2004-2012. By utilizing from time series model, the author reports a significant and positive correlation between the amount of CDS net notional outstanding and bond market liquidity. The bond market liquidity and the amount of CDS purchased are correlated with credit risk and the size of the bond market (Sambalaibat, 2014).

Bozkurt (2015) investigated the impact of financial stability indicators (credit/savings, gross default account receivable amount/gross credit amount, net default account receivables/equity capital, fixed assets/total assets, liquid assets/total asset s, net profit/capital, net profit/total assets, free capital/total asset, equity capital/total asset, outstanding debt of non -financial sector/GDP, bank interest rates for saving accounts, inflation rate, GDP growth, interest rate for government borrowing) on CDS premiums through fuzzy regression analysis covering the period of 2002-2014. The researcher reports a positive correlation between CDS and rates of government bond interest and inflation.

Bekkour et al. (2015) studied Eurozone during the debt crisis period for the relationship between EU member countries credit worthiness and the common currency of Euro. As a result, authors concluded that creditworthiness of member countries with vulnerable fiscal positions have a significant effect on the deviation of the common currency.

Başarır and Keten (2016) studied the relationship between CDS premiums and stock market index and currency rates of 12 emerging countries in terms of short and long term correlation for the period of 2010-2016 by means of Granger causality test and by the Johansen Cointegration test, respectively. Authors address bi-directional causality relationship between CDS premiums and stock market indexes at $95 \%$ significance level. However, no any causality relationship is found with currency rate neithe $r$ in the short or long term.

Similarly, Karet al. (2016) investigated the relationship between CDS and currency rate (Euro/TRL) by employing an asymmetric causality test developed by Hatemi-J and Roca (2014) for the period of 2009 and 2015 in which different shocks were experienced. The researchers report bi-directional negative relationship between CDS and EUR/TL exchange rate by means of the MS VAR method. Their results unravel the existence of a causation link between CDS and nominal exchange rate on the long term. Additionally, the rolling windows causality analysis results expose the causal relationship from CDS spreads to EUR/TL exchange rate only in 2013 and 2015.

The empirical studies above are largely oriented on the relationship between CDS and macroeconomic indicators, market indices and other derivatives. It is seen that majority of studies detect significant relationship between concerned variables at various levels depends on characteristics of their analyses It is important to recognize the influence of time period concerned (e.g. crisis period or not) and statistical methods employed during these investigations on data series. For instance, whereas correlation among variables become more visible during crisis periods, the strength of correlation erodes along the relatively stable periods. Additionally, Granger and Garch model-based statistical methods yield significant but weak relationships, while the models derivatives of regression yield stronger and significant correlation. The results of majority of studies available in the rel evant literature such as Chan-Lau and Kim (2004), Norden and Weber (2009), Zhang et al. (2009), Yang et al.(2010), Özkaplan (2011), O'Kane (2012), Koy (2014), Sambalaibat (2014), and Bekkour et al. (2015) are found to be parallel with the present study. On the other hand, the study of Başarır and Keten (2016) find no relationship between CDS and foreign currencies of 12 emerging countries including Turkey. Yang et al. (2010) reveal positive and negative correlations between CDS and foreign exchange for France and the U.S, respectively. Kar, Bayat and Kayhan (2016) report negative correlation between CDS and Euro/TL rate.

This study includes the most prominent three developing countries highly dependent on foreign funds, sensitive to fluctuations in CDS spreads and known as "fragile three" instead of sampling developed countries. In the meantime, new generation econometric methods were employed for an extensive analysis period in the light of recent investment banking agenda. Thus, it is considered that a certain contribution would be made to the relevant literature.

\section{DATA AND METHODOLOGY}

In this study, the relationship between Credit Default Swap (CDS, logarithmic), Government Bond Interest Rate (BIR, 5 -Year Bond Yield for Turkey, 10-Year Bond Yield for South Africa and Brazil) and nominal Foreign Exchange (FX, USD) was an alyzed for F3 countries for the period from 2007M2-2017M1. The period from 2007M2 to 2017M1 was preferred because the most robust data was obtained for this period. The logarithm of the CDS has been taken for easy interpretation. Time series used in the st udy are collected from monthly data (120 monthly observations) published by Bloomberg L.P. (Bloomberg, 2017) and investing.com (Investing, 2017). Eviews and GAUSS programs were used during the analysis phase. The effects of the BIR and FX varibles on CDS were analyzed separately and the following model is estimated for each country; 


$$
\operatorname{CDS}_{i t}=\alpha_{0}+\alpha_{1} B I R_{i t}+\alpha_{2} F X_{i t}+u_{i t}
$$

Where, $i$ and $t$ refercountries (Brazil, Turkey, South Africa) and time, respectively; while $\alpha_{0}$ is constant term, $\alpha_{1}$ is coefficient of $\mathrm{BIR}, \alpha_{2}$ is coefficient of $\mathrm{FX}$ and $u$ is the error term.

The stationary of the series was analyzed by Kapetanios's (2005) multiple structural break unit root test, the evidence for existence of cointegration was investigated by Johansen Cointegration Test (1990) and the causality relationship among series was examined by Toda-Yamamoto (1995) causality test (TY).

\subsection{Kapetanios (2005) Multiple Structural Break Unit Root Test}

The stability of time series means that it has a constant mean and variance, covariance relat ed to lag level and approximation a certain value in time (Gujarati and Porter, 2012:740). However, potential structural breaks in time series need to be taken into consideration otherwise unit root analyzes could result in misleading inferences (Perron, 1989). The structural break unit root test was first included in the empirical studies conducted by Perron (1989) and continued by Zivot-Andrews (1992), Lumsdaine-Papell (1997), Perron (1997), Ng-Perron (2001) and Lee-Strazicich (2003). While these methods reckon one or two structural breaks in the series, the Kapetanios (2005) test takes into account up to five structural breaks, the number of breaks and break points can be determined internally by the test method. The model used in this test is as follows (Kapetanios, 2005):

$$
\begin{aligned}
& y_{t}=\alpha_{0}+\alpha_{1} t+\beta y_{t-1}+\sum_{i=1}^{p} \gamma_{i} \Delta y_{t-i}+\sum_{i=1}^{m} \varphi_{i} D U_{t, t}+\sum_{i=1}^{m} \mathrm{x}_{i} D T_{i t}+\epsilon_{t} \\
& D U_{i, t}=\left\{\begin{array}{rr}
1 & t>T_{b, i} \\
0 & \text { in other situations }
\end{array} \text { and } D T_{t, t}=\left\{\begin{array}{rr}
t-T_{b, 1} & t>T_{b, i} \\
0 & \text { in other situations }
\end{array}\right.\right.
\end{aligned}
$$

$D U$ and $D T$ are intercept and trend break dummy variables respectively; and null hypothesis of the test is defined as " $B=1$, series contain unit root". In this test, structural break points are determined by using grid search schem e of Bai and Perron (1998) due to the convenience of application (Kapetanios, 2005: 127). In this context, initially each period is considered as a probable structural break date and the date on which has the minimum sum of squared residuals (SSR) is accep ted as a first break date. Then this date is kept constant and the second break date is investigated (Murat et al., 2013). These steps are repeated until $m$ break dates, and finally number of structural breaks and break dates which have minimum $t$ statistics values are accepted (Capistrán and Ramos-Francia, 2009). In this study, maximum lag length was set to 12 by using Equation (3) developed by Schwert (1988). Where $k$ denotes maximum lag length, $T$ denotes the number of observations. Table 1 exhibits Kapetani os (2005) multiple structural break test results; and charts of the series are given in the Appendix.

$$
k=12 \times(T / 100)^{1 / 4}
$$

\begin{tabular}{|c|c|c|c|c|}
\hline & & $\tau$-statistic & $\begin{array}{c}\text { Critical } \\
\text { Value (\%1) }\end{array}$ & Structural Break Dates \\
\hline \multirow{3}{*}{ Turkey } & CDS & -4.564 & -5.954 & 2009M3-2011M4-2012M12-2015M5 \\
\hline & $B I R$ & -5.846 & $-9,039$ & 2008M6-2009M11-2011M12-2012M10-2015M8 \\
\hline & $F X$ & -6.152 & -9.039 & 2008M9-2010M6-2011M9-2014M1-2015M4 \\
\hline \multirow{3}{*}{ Brazil } & $C D S$ & -7.695 & -9.039 & 2009M2-2012M1-2012M8-2014M7-2015M7 \\
\hline & $B I R$ & -7.457 & $-9,039$ & 2008M9-2011M5-2012M4-2014M3-2015M8 \\
\hline & $F X$ & -5.610 & $-9,039$ & 2009M2-2011M5-2013M2-2014M1-2015M6 \\
\hline \multirow{3}{*}{ South Africa } & $C D S$ & -4.693 & $-6,192$ & 2008M4-2010M4-2011M7-2014M11-2016M7 \\
\hline & $B I R$ & -4.899 & -9.039 & 2008M4-2010M6-2012M6-2014M9 \\
\hline & $F X$ & -5.610 & $-9,039$ & 2009M3-2011M8-2012M9-2014M6-2015M8 \\
\hline
\end{tabular}

Table 1: Kapetanios (2005) Multiple Structural Break Unit Root Test 


\begin{tabular}{|l|c|c|c|c|}
\hline \multirow{4}{*}{ Turkey } & $\Delta C D S$ & $-11,412^{* * *}$ & $-7,395$ & 2008M12-2009M12-2011M12-2013M8-2016M5 \\
\cline { 2 - 5 } & $\Delta B I R$ & $-10,057 * * *$ & $-6,856$ & 2008M12-2010M9-2013M3-2014M8 \\
\cline { 2 - 5 } & $\Delta F X$ & $-10,914 * * *$ & $-7,395$ & 2008M8-2010M9-2014M7-2015M11-2016M7 \\
\hline \multirow{4}{*}{ Brazil } & $\Delta C D S$ & $-10,168 * * *$ & $-7,395$ & 2009M3-2011M5-2012M5-2015M4-2015M12 \\
\cline { 2 - 5 } & $\Delta B I R$ & $-11,411^{* * *}$ & $-7,395$ & 2009M1-2010M7-2012M7-2015M4-2015M9 \\
\cline { 2 - 5 } & $\Delta F X$ & $-10,113^{* * *}$ & $-7,395$ & 2008M10-2010M3-2013M7-2015M3-2015M8 \\
\hline \multirow{3}{*}{ South Africa } & $\Delta C D S$ & $-10,223 * * *$ & $-7,395$ & 2009M5-2010M9-2015M5-2016M1-2016M6 \\
\cline { 2 - 5 } & $\Delta B I R$ & $-9,534 * * *$ & $-7,395$ & 2008M6-2010M9-2013M3-2014M8-2015M10 \\
\cline { 2 - 5 } & $\Delta F X$ & $-10,071 * * *$ & $-7,395$ & 2008M12-2010M1-2011M7-2015M5-2015M11 \\
\hline
\end{tabular}

Note: $* * *$ denotes significance at the $\% 1$ level. Test statistics were obtained with codes written for the Gauss program. Critical values were obtained with 1.000 bootstrap replications.

According to Table 1, the levels of variables have a unit root, on the other hand when their first difference is taken, they become stationary; I(1). Based on the structural break dates indicated by the test method, the important structural break dates observed with the F3 countries corresponded with the period of 2008-2009. 2008 global crisis first caused immediate shocks in currency rates and interest rates. Uncertainty caused by the global crisis increased CDS premiums of Brazil, South Africa and Turkey in the beginning of 2009. As a respond, policy makers increased intere st rates significantly for managing the ongoing crisis. However, as a consequence of the crisis, economies of these three countries contracted remarkably in 2009; and experienced recession. By the end of 2009, Turkey made significant reforms with banking auditing protocols and regulations after the previous crises. In the same year with a provided in confidence, CDS premiums and interest rates declined significantly in Turkey to 183 and $9.87 \%$, respectively. As the European debt crisis deepened further, it caused serious disagreements across the EU in 2011; and threatened the future of the Euro currency. This situation affected Turkey's CDS premium adversely. In the same period, the Brazilian g rowth rate started to decrease and its currency depreciated significantly. Accordingly, CDS premiums for Brazil and therefore interest rates in the country increased. In 2010 and 2011, it was seen that there was a fluctuation in South Africa's CDS rates betwee $n 125$ and 174. Especially in this period, high unemployment rates, low growth rate and low saving rates in South Africa have resulted in middle-income trap, fragility and economic fluctuations (Kumo, 2015). It was observed that after the Fed's statement that it would decrease government bond purchase and follow tight monetary policy by increasing interest rates in May 2013, F3 countries sufered to access foreign funds. Moreover, another significant adverse impact on developing countries was decreasing Chinese foreign investment on these countries (Göçer and Akın, 2016). National currencies of developing countries have devalued remarkably. Especially, as a result of an interest rate increase by the Turkish Central Bank by $4.25 \%$ in January 2014 was acknowledged that Turkey was the most fragile country among others (Landon, 2014). Increasing currency and interest rate risk with F3 countries in the period of 2014-2015 was the factor increasing their cost of foreign funding. In the same period, factors such as low growth rate, decreasing industrial production and increasing government debt in Brazil caused $139 \%$ increase in CDS premium of this country from the beginning of 2014 to the end of 2015. In South Africa case, stagflation, twin deficits and $h$ igh debt across sectors caused CDS premium of this country to increase unt il the beginning of 2016 and increased the risk associated with foreign debt management of the country as recorded 356, the highest level since the 2008 crisis. After May 2015, CDS premium has increased up to 312 for Turkey, it continued further because of economic and political risk factors. For example, the military coup attempt experienced in July 2016 repelled foreign capital, which resulted in the devaluation of TL against fore ign currencies by about $26 \%$ in Turkey.

\subsection{Johansen Cointegration Analysis}

Cointegration relationship between CDS, BIR and FX was analyzed by using Johansen Cointegration Test (1990). This test allows working with the level values of the series and the analysis of cointegration with more than one variable is more reliable. On the basis of structural break dates observed with the Kapetanios (2005) multiple structural break unit root test, two or three break dates that showed similarity and gave the best results were selected and included in the analysis as dummy variable at this $p$ oint. Table 2 exhibits results of Johansen Cointegration Test. For each country, different lag levels were determined by using sequential modified LR test statistic (each test at $5 \%$ level). 
Table 2: Johansen Cointegration Test Results

\begin{tabular}{|c|c|c|c|c|c|c|c|}
\hline \multicolumn{8}{|c|}{ TURKEY (with 12 lags) } \\
\hline \multicolumn{4}{|c|}{ Trace Test } & \multicolumn{4}{|c|}{ Maximum Eigenvalue Test } \\
\hline $\begin{array}{l}\text { Null }\left(H_{0}\right) \\
\text { Hypothesis }\end{array}$ & $\begin{array}{l}\text { Alternative } \\
\text { Hypothesis }\end{array}$ & $\lambda_{\text {trace }}$ & $\begin{array}{c}\% 5 \text { Critical } \\
\text { value }\end{array}$ & $\begin{array}{c}\text { Null }\left(H_{0}\right) \\
\text { Hypothesis }\end{array}$ & $\begin{array}{l}\text { Alternative } \\
\text { Hypothesis }\end{array}$ & $\lambda_{\max }$ & $\begin{array}{c}\% 5 \text { Critical } \\
\text { value }\end{array}$ \\
\hline$r=0 *$ & $r>0$ & 46.147 & 35.192 & $r=0 *$ & $r=1$ & 23.852 & 22.292 \\
\hline$r \leq 1^{*}$ & $r>1$ & 22.295 & 20.261 & $r=1^{*}$ & $r=2$ & 16.116 & 15.892 \\
\hline$r \leq 2$ & $r>2$ & 6.179 & 9.1645 & $r=2$ & $r=3$ & 6.179 & 9.1645 \\
\hline \multicolumn{8}{|c|}{ BRAZIL (with 15 lags) } \\
\hline \multicolumn{4}{|c|}{ Trace Test } & \multicolumn{4}{|c|}{ "Maximum Eigenvalue Test } \\
\hline $\begin{array}{l}\text { Null }\left(H_{0}\right) \\
\text { Hypothesis }\end{array}$ & $\begin{array}{l}\text { Alternative } \\
\text { Hypothesis }\end{array}$ & $\lambda_{\text {triace }}$ & $\begin{array}{l}\% 5 \text { Critical } \\
\text { value }\end{array}$ & $\begin{array}{c}\text { Null }\left(H_{0}\right) \\
\text { Hypothesis }\end{array}$ & $\begin{array}{l}\text { Alternative } \\
\text { Hypothesis }\end{array}$ & $\lambda_{\max }$ & $\begin{array}{c}\text { \%5 Critical } \\
\text { value }\end{array}$ \\
\hline$r=0 *$ & $r>0$ & 49.996 & 35.192 & $r=0 *$ & $r=1$ & 31.341 & 22.299 \\
\hline$r \leq 1$ & $r>1$ & 18.655 & 20.261 & $r=1$ & $r=2$ & 14.845 & 15.892 \\
\hline$r \leq 2$ & $r>2$ & 3.809 & 9.164 & $r=2$ & $r=3$ & 3.806 & 9.164 \\
\hline \multicolumn{8}{|c|}{ SOUTH AFRICA (with 6 lags) } \\
\hline \multicolumn{4}{|c|}{ Trace Test } & \multicolumn{4}{|c|}{ Maximum Eigenvalue Test } \\
\hline $\begin{array}{l}\text { Null }\left(H_{0}\right) \\
\text { Hypothesis }\end{array}$ & $\begin{array}{l}\text { Alternative } \\
\text { Hypothesis }\end{array}$ & $\lambda_{\text {trace }}$ & $\begin{array}{c}\% 5 \text { Critical } \\
\text { value }\end{array}$ & $\begin{array}{l}\text { Null }\left(H_{0}\right) \\
\text { Hypothesis }\end{array}$ & $\begin{array}{l}\text { Alternative } \\
\text { Hypothesis }\end{array}$ & $\lambda_{\max }$ & $\begin{array}{c}\% 5 \text { Critical } \\
\text { value }\end{array}$ \\
\hline$r=0 *$ & $r>0$ & 62.406 & 35.192 & $r=0 *$ & $r=1$ & 29.63173 & 22.299 \\
\hline$r \leq 1^{*}$ & $r>1$ & 32.774 & 20.261 & $r=1^{*}$ & $r=2$ & 24.17656 & 15.892 \\
\hline$r \leq 2$ & $r>2$ & 8.597 & 9.164 & $r=2$ & $r=3$ & 8.597814 & 9.164 \\
\hline
\end{tabular}

Note:* suggests rejecting null hypothesis.

According to results in Table 2, both trace and maximum Eigen value tests suggest that there single eventual cointegration relationship between variables related with Brazil. For Turkey and South Africa, it could be said that there was at most two cointegration relationships. These results showed that the variables of fragile three countries act together in the long run period. Within this framework, the cointegration equations could be rewritten as below:

Model $_{\text {rurker }}$

$$
\begin{aligned}
C D S_{T R}= & 4.595944+0.046029 B I R_{T R}+0.154389 F X_{T R} \\
& {[-20.2098][-4.58661] \quad[-2.54685] }
\end{aligned}
$$

Model $_{\text {Brazit }}$

$$
\begin{aligned}
& C D S_{B R}=3.099183+0.069537 B I R_{B R}+0.518351 F X_{B R} \\
& {[-11.5710] \quad[-3.51842] \quad[-5.71149]} \\
& C D S_{S A}=2.160397+0.297605 B I R_{S A}+0.145274 F X_{S A} \\
& {[-1.96989] \quad[-2.02940] \quad[-2.54064]}
\end{aligned}
$$$$
\text { Model }_{\text {SAfriea }}
$$

Estimate of equations show that the impact of government bond interest rate and foreign exchange rate of USD on CDS fragile three countries is positive and statistically significant.

On the basis of the results of conducted analyses exhibited on Table 3 above, a positive and significant correlation was determined among CDS, interest rate and local currencies of F3 countries. A unit of increase in interest rate and currency in Turkey inc rease 
CDS premium by 0.05 and 0.15 units, respectively. In Brazil case, it increased CDS premium by 0.07 and 0.52 units respectively; in South Africa case, it increased CDS premium by 0.30 and 0.15 units, respectively.

\subsection{The Error Correction Model}

Dynamic behaviour of cointegrated variables in the long-term equilibrium displays deviations in the short run. If the system returns to equilibrium in the long run, these deviations should be removed. To analyze this situation, the error correction model is applied to variables. The results of ECM are reported in Table 3.

Table 3: Results of Error Correction Model

\begin{tabular}{ccccccccccc}
\hline & $E C_{t-1}$ & $\Delta C D S_{t-1}$ & $\Delta B I R_{t-1}$ & $\Delta F X_{t-1}$ & $K_{200}$ & $K_{2011}$ & $K_{2014}$ & $R^{2}$ & $R^{2}$ & F-Statistics \\
\hline Model $_{\text {Turkey }}$ & -0.627 & 0.202 & -0.038 & 0.252 & 0.050 & -0.001 & - & 0.45 & 0.19 & 1.696 \\
& {$[-3.804]$} & {$[1.040]$} & {$[-1.767]$} & {$[0.951]$} & {$[1.917]$} & {$[-0.023]$} & - & & \\
\hline Model $_{\text {Brazit }}$ & -0.741 & 0.410 & -0.099 & 0.119 & 0.139 & - & -0.080 & 0.56 & 0.24 & 1.763 \\
& {$[-4.103]$} & {$[2.062]$} & {$[-3.684]$} & {$[0.531]$} & {$[3.801]$} & - & {$[-1.765]$} & & & \\
\hline Model $_{\text {SAfrica }}$ & -0.114 & -0.125 & -0.190 & 0.113 & -0.149 & 0.047 & -0.050 & 0.29 & 0.16 & 2.199 \\
& {$[-3.394]$} & {$[-1.135]$} & {$[-3.954]$} & {$[2.378]$} & {$[-3.097]$} & {$[1.184]$} & {$[-1.157]$} & & & \\
\hline \hline
\end{tabular}

Note: [ ] indicates t-statistics value.

According to the results of the error correction model, it shows that the deviations occurring in the short term in all three countries disappear in the long term and the series converges again to the long term equil ibrium values. The difference between observed values and long-term equilibrium values of CDS figures is eliminated within 2 months for Turkey and Brazil, within 9 months for South Africa.

\subsection{Todo Yamamoto(1995) Causality Test}

The Toda-Yamamoto (1995) causality test (TY) was conducted in order to obtain robust results of the causality relationship between CDS, interest and exchange rate of F3 countries. In this method, the series can be included in the analysis without the need for knowledge such as stationary and cointegration, there by the loss of observations are shortened by this method (Gune $s$, et al. 2016).

Firstly, the optimum lag length $(k)$ is determined by using VAR. The maximal order of integration (dmax) is added to kin the second stage. And then, the VAR model is estimated with the levels of series according to $(k+d m a x)$ lag length. As this stage, estimated VAR model is similar for the three countries as follows:

$$
\begin{aligned}
& \mathrm{CDS}_{t}=\alpha_{0}+\sum_{i=1}^{k+d_{\max }} \alpha_{1 i} \operatorname{CDS}_{t-4}+\sum_{i=1}^{k+d_{\max }} \alpha_{2 i} \operatorname{BIR}_{t-i}+\sum_{i=1}^{k+d_{\max }} \alpha_{3 i} \mathrm{FX}_{t-i}+\mu_{t} \\
& \mathrm{BIR}_{t}=\beta_{0}+\sum_{\mathrm{i}=1}^{\mathrm{k}+\mathrm{d}_{\max }} \beta_{1 i} \mathrm{BIR}_{\mathrm{t}-\mathrm{i}}+\sum_{\mathrm{i}=1}^{\mathrm{k}+\mathrm{d}_{\max }} \beta_{2 i} \mathrm{CDS}_{t-\mathrm{i}}+\sum_{\mathrm{i}=1}^{\mathrm{k}+\mathrm{d}_{\max }} \beta_{3 i} \mathrm{FX}_{t-4}+\mu_{t} \\
& \mathrm{FX}_{t}=\gamma_{0}+\sum_{i=1}^{\mathrm{k}+\mathrm{d}_{\max }} \gamma_{1 i} \mathrm{FX}_{t-i}+\sum_{\mathrm{i}=1}^{\mathrm{k}+\mathrm{d}_{\max }} \gamma_{2 i} \mathrm{CDS}_{\mathrm{t}-\mathrm{i}}+\sum_{\mathrm{i}=1}^{\mathrm{k}+\mathrm{d}_{\max }} \gamma_{2 i} \mathrm{BIR}_{t-i}+\mu_{t}
\end{aligned}
$$

At the last stage, restrictions are applied on coefficients ofd max $_{\text {; }}$ and significances of restrictions are tested by employing the MWALD test. The null hypothesis of test is "there is no causality".

In this analysis, $k$ was determined according to sequential modified LR test statistic for each country ( $k$ is $12,15,6$ for Turkey, Brazil and South Africa, respectively). There was no autocorrelation and heterogeneity in the VAR model. The maximal order of integration $\left(d_{\text {max }}\right)$ is estimated at 1 because variables are I(1); then regression models were estimated with $k+d_{\text {max }}$ lag length. Results of TY test are presented in Table 4. 
Table 4: Results of Todo Yamamoto Causality Test

\begin{tabular}{|c|c|c|c|c|}
\hline & Null Hypothesis & $\begin{array}{c}\text { Lag Length } \\
k=12,15,6 d_{\max }=1\end{array}$ & $\begin{array}{c}\chi^{2} \\
\text { Statistics }\end{array}$ & Probability \\
\hline \multirow{6}{*}{ Turkey } & $C D S \Rightarrow B I R$ & 13 & $47,03 * * *$ & 0,00 \\
\hline & $C D S \Rightarrow F X$ & 13 & $25,77^{* * *}$ & 0,02 \\
\hline & $B I R \nRightarrow C D S$ & 13 & $35,70 * * *$ & 0,00 \\
\hline & $B I R \nRightarrow F X$ & 13 & $44,97 * * *$ & 0,00 \\
\hline & $F X \nRightarrow C D S$ & 13 & $21,85^{* *}$ & 0,06 \\
\hline & $F X \nRightarrow B I R$ & 13 & $26,60 * * *$ & 0,01 \\
\hline \multirow{6}{*}{ Brazil } & $C D S \nRightarrow B I R$ & 16 & $46,79 * * *$ & 0,00 \\
\hline & $C D S \nRightarrow F X$ & 16 & $24,81 * *$ & 0,07 \\
\hline & $B I R \nRightarrow C D S$ & 16 & $25,23 * *$ & 0,07 \\
\hline & $B I R \nRightarrow F X$ & 16 & 10,22 & 0,85 \\
\hline & $F X \nRightarrow C D S$ & 16 & $36,89 * * *$ & 0,00 \\
\hline & $F X \nRightarrow B I R$ & 16 & $50,87^{* * *}$ & 0,00 \\
\hline \multirow{6}{*}{ South Africa } & $C D S \nRightarrow B I R$ & 7 & 6,90 & 0,44 \\
\hline & $C D S \nRightarrow F X$ & 7 & 6,69 & 0,46 \\
\hline & $B I R \nRightarrow C D S$ & 7 & $20,89 * * *$ & 0,00 \\
\hline & $B I R \nRightarrow F X$ & 7 & $33,09 * * *$ & 0,00 \\
\hline & $F X \nRightarrow C D S$ & 7 & $15,02 * *$ & 0,04 \\
\hline & $F X \nRightarrow B I R$ & 7 & 7,95 & 0,34 \\
\hline
\end{tabular}

Note: $* * *, * *$ denotes significance at the $\% 1$ and $\% 5$ level, respectively.

The results suggested bi-directional causality between the CDS and the exchange rate and the interest rate in Turkey and Brazil. However, for South Africa, the causality between the CDS and the exchange rate and the interest rate was unidirectional; the exchange rate and the interest rate were found to be cause of the CDS.

Obtained results are conforming to the majority of findings in the relevant literature s such as Yang et al. (2010), Özkaplan (2011), Koy (2014), Norden and Weber (2009), Sambalaibat (2014), Chan-Lau and Kim (2004), Zhang et al. (2009), Bekkour et al. (2015), O'Kane (2012). On the other hand, the study of Başarır and Keten (2016) finds no relationship between CDS and foreign currencies of 12 emerging countries including Turkey. Yang et al. (2010), reveal positive and negative correlations between CDS and foreign exchange for France and the U.S, respectively. Kar, Bayat and Kayhan (2016) report negative correlation between CDS and Euro/ $7 \mathrm{~L}$ rate. This study included the most prominent three developing countries highly dependent on foreign funds, sensitive to fluctuations in CDS spreads and known as "fragile three" instead of sampling developed countries. In the meantime, new generation econometric methods were employed for an extensive analysis period in the light of recent investment banking agenda. Thus, it was considered that a certain contribution would be made to the relevant literature.

\section{CONCLUSION}

The primary common characteristic of these three countries was their need for external funding. Sensitivity of these countries towards external and internal economic developments and abundance of factors stimulating relevant risks have negative impact on their fragility. The main risk for foreign investors is the loss of their capital and/or expected return on their investment. There fore, investors consider risks based on indicators such as CDS premiums, indicator of country credibility, interest rates and local currencies differently from each other. From the point of emerging markets, the increasing country risk caused by adverse economic conditions would complicate to find extemal finance, which will cause the exchange rates to increase and the country to raise interest rates in order to attract foreign financing. The general expectation is that the higher the CDS premium, the higher the funding cost is (Eğilmez, 2013). Indeed, this status would differ with respect to the current political and economic conjuncture of individual countries. 
In this paper, causality relationship among individual CDS, BIR and FX (domestic currency/USD) data from Brazil, South Africa and Turkey referred as "Fragile Three" was investigated through new generation econometric analysis methods for the period of 2007M2-2017M1. Findings could be classified in three main topics. According to the Kapetanios (2005) structural -fractural unit root test results, it was seen that country CDS, BIR and FX indicators are highly sensitive to financial crisis. Although fundamental causes of crises differ, country risk phenomenon is always adversely influenced by this circumstance. Moreover, developments threatening political and economic stability, for example, the military coup in Turkey, middle-income gap in South Africa, both unstable economic growth and low savings rates in F3 countries were also considered as a factor with negative influence on country risk, which could, in turn, have a negative impact on country credibility. Secondly, it was seen that CDS premium, interest rates and local currencies of $\mathrm{F} 3$ countries exhibited similar behavior on the long term; and that short term deviations returned to their long term equilibrium value.

F3 countries need to offer higher interest rate to attract greater foreign capital from the market under their current economic and political risks. According to positive relationship between BIR and CDS, the increase in interest rates will not provide the expected foreign fund inflow into these countries. Positive relationship between FX and CDS is found. Increasing risk associated with an economy is considered as the factor limiting inflowing of foreign funds and thus elevating currency rates. Cointegrat ion coefficients obtained with the F3 countries were found to be statistically significant.

Third and finally, the results revealed bi-directional causality between the CDS and the FX and BIR in both Turkey and Brazil. However, for South Africa, the causality between the CDS and FX rate and BIR was found to be unidirectional whereas FX and BIR were found to be causes of the CDS. It could be suggested that the increase of BIR and FX would be resulted in adverse effect s on macroeconomic indicators of F3 countries because of the pass through effect. As a result of this, the economic fragility and the risk premium of countries would be increased. The acquired results also showed that the increase in the CDS lead to an increa se in the risk perception toward the relevant country and an outflow of foreign capital; and finally, it causes an increase in FX and BIR especially in Brazil and Turkey.

Our findings suggested that these variables of F3 countries were influenced substantially from each other. The necessary econ omic policies should be developed to ensure permanent stability with FX and BIR indicators of these countries. In order to attract foreign investments and to reduce the perception of risky countries, F3 countries should reduce their BIR gradually and at the same $t$ ime to ensure stability with their FXs. Moreover, a strong central bank reserve is required for stability in respective countries' currencies. In order to ensure that F3 countries maintain their financial stability, certain economic, political and social reforms are required through minimizing country risks and decreasing dependency on foreign capital.

\section{REFERENCES}

Augustin P., Subrahmanyam M. G., Tang, D. Y., \& Wang S. Q. (2016). Credit default swaps: Past, present, and future. The Annual Review of Financial Economics, 8(10): 1-10.22.

Bai, J. \& Perron, P. (1998). Estimating and testing linear models with multiple structural changes. Econometrica, 66 (1): 47-78.

Başarır Ç. \& Keten M. (2016). A Cointegration analysis between CDS premiums, stock indexes and exchange rates in Emerging countries. MAE Univeristy Social Sciences Periodical, 8(15): 369-380

Bekkour, L., Jin, X., Lehnert, T., Rasmouki, F. \& Wolff, C. (2015). Euro at risk: The impact of member countries' credit risk on the stability of the common currency. Journal of Empirical Finance, 33: 67-83.

Bernanke, B. \& Gertler, M. (1990). Financial fragility and economic performance. The Quarterly Journal of Economics, 105 (1): $87-114$.

Bloomberg Statistical Database, www. bloomberg.com, [Accessed 2017]

Breuer A. \& Sauter O. (2013). Calculating the unthinkable: Exchange rate effects of a credit event. Applied Economics Quarterly, Berlin, 58(1): 118.

Bozkurt, i., (2015). Determination of the relationship between financial stability and CDS premiums by using fuzzy regression analysis: Turkey case. Gümüşhane University, Electronic Periodical of Social Sciences, 6(13): 64-80.

Capistrán, C. \& Ramos-Francia, M. (2009). Inflation dynamics in Latin America. Contemporary Economic Policy, 27(3): 349-362.

Chan-Lau, J. \& Kim Y. (2004). Equity prices, credit default swaps, and bond spreads In Emerging Markets. IMF Working Paper No. 27.

O'Kane, D. (2012). The link between Eurozone sovereign debt and CDS prices. EDHEC-Risk Institute Report

Duffee, D. (1999). Credit swap valuation. Financial Analysist Journal, 55: 73-87. 
Eğilmez, M. (2013). Foreing exchange, interest, government bond, BIST, credit ranking, CDS briefly. Kendime Yazılar, http://www.mahfiegilmez.com/2013/07/kur-faiz-dibs-bist-reyting-cds-hepsi.html. [Accessed 15 February 2017].

ETF Trends (2017). Emerging market ETFs: Keep wath over the fragile three. https://www.etftrends.com/2015/03/emerging-market-etfs-keepwatch-over-fragile-three. [Accessed February 2017].

Flannery, M.J., Houston J.F. \& Partnoy F. (2010). Credit default swap spreads as viable substitutes for credit ratings. University of Pennsy/vania Law Review, 158: 2085.

Fontana, A. \& Scheicher, M. (2010). An analysis of Euro Area sovereign CDS and their relation with government bonds. European Central Bank Working Paper Series - 1271.

Gonzalo, J. \& Granger, C. (1995). Estimation of common long-memory components in cointegrated systems. Journal of Business \& Economic Statistics, 13(1): 27-35.

Göçer, I. \& Akin, T. (2016). The effects of saving-Investment gap on economic growth in the Fragile Five: A new generation econometric analysis. Ege Akademik Bakış, 16(2):197.

Gujarati, D. N. \& Porter, D. (2012). Temel ekonometri. Translated by: Şenesen, Ü., Şenesen, G. G., İstanbul, Literatür Press.

Gunes, S., Polat, F. \& Akin, T. (2016). Kalkınma bağlamında büyüme, yolsuzluk ve demokrasi ilişkisi. Economic Development Social and Political Interactions, Ijopec Publication No: 25: 13-21, Turkey. ISBN: 978-0-9932118-5-0.

Hasbrouck, J. (1995). One security, many markets: determining the contributions to price discovery. The Journal of Finance, 50(4): 1175-1199.

Hatemi-J, A. \& Roca, E. (2014). BRICS and PIGS in the presence of Uncle Sam and Big Brothers: Who drive who? evidence based on asymmetric causality tests. Available online: http://econpapers.repec.org/paper/griapaper/finance_3a201401.htm [Accessed February 2017].

Investing Statistical Database (2017), the relevant link: https://tr.investing.com/currencies/usd-try-chart [Accessed February 2017]

Johansen, S. \& Juselius K. (1990). Maximum likelihood estimation and inference on cointegration-with applications to the demand for Money. Oxford Bulletin of Economics and Statistics, 52(2): 169-210.

Kapetanios, G. (2005). Unit-root testing against the alternative hypothesis of upto m structural breaks. Journal of Time Series Analysis, Vol.26 (1): 123-133.

Kar, M., Bayat, T. \& Kayhan, S. (2016). Impacts of credit default swaps on volatility of the exchange rate in Turkey: The cas e of Euro. International Journal of Financial Studies, 4 (14): 1-18.

Kargi, B. (2014). Credit default swap (CDS) spreads: the analysis of time series for the integration with the interest rates and the growth in Turkish economy. Montenegrin Journal of Economics, 10(1), 59-66.

Koy, A. (2014). An emprical study on credit default swaps and on bonds. Istanbul Ticaret University, Working Paper Series, Discussion Papers, WPS NO/ 01 / 2014-07: 1-12.

Kumo, W.L. (2015). Inflation Targeting Monetary Policy, Inflation Volatility and Economic Growth in South Africa. African Development Bank Group, Working Paper Series, No. 216, January.

Landon, T. J. (2014). Fragile five is the latest club of emerging nations in turmoil. New York Times, http://www.nytimes.com/2014/01/29/business/international/fragile-five-is-the-latest-club-of-emerging-nations-in-turmoil, [Accessed February 2017].

Lee, J. \& Strazicich, M.C. (2003). Minimum lagrange multiplier unit root test with two structural breaks. The Review of Economics and Statistics, 85 (4): 1082-1089.

Lumsdaine, R. L. \& Papell, D.H. (1997). Multiple trend breaks and the unit root hypothesis. The Review of Economics and Statistics, 79: $212-218$.

Mora, N. (2006). Sovereign credit ratings: Guilty beyond reasonable doubt? Journal of Banking \& Finance, 30(7): 2041-2062.

Mora-Jensen, D. S. (2013). The relationship between the exchange rate and sovereign credit default swaps: An empirical analysis. Master Thesis, (May 27th, 2013), Copenhagen Business School.

Morgan Stanley Research Report (2013). FX Pulse. http://www.morganstanleyfa.com/public/projectfiles/dce4d168-15f9-4245-9605e37e2caf114c. pdf [Accessed February 2017].

Murat, S., Şener, S. \& Yılancı, V. (2013). Economic crises, natural disasters, terror activities and their impact on tourists vistiing Turkey? Periodicle of Faculty of Economics, 63(1): pp. 1-15.

Ng, S. \& Perron, P. (2001). Lag length selection and the construction of unit root tests with good size and power. Econometrica, Vol.69: 1519-1554. 
Norden, L. \& Weber, M. (2009). The Co-movement of credit default swap, bond and stock markets: An empirical analysis. European Financial Management, 15(3): 529-562.

Özkaplan, D. (2011). Turkish credit default swaps and relationship with financial indicators. Graduate Study Thesis, İstanbul Bilgi University.

Perron, P. (1989). The great crash, the oil price shock, and the unit root hypothesis. Econometrica, 57(2): 1361-1401.

Perron, P. (1997). Further evidence on breaking trend functions in macroeconomic variables. Journal of Econometric, 80: 355-385.

Sambalaibat, B. (2014). Essays in financial economics: Currency risk and pricing Kernal volatility, CDS and sovereign bond market liquidity, CDS as sovereign debt collateral. Carnegie Mellon University, Doctorate Study Thesis.

Schwert, W. G. (1988). Tests for unit roots: A Monte Carlo investigation. NBER Technical Working Paper Series, No: 73.

Skinner, F. S. \& Townend, T. G. (2002). An empirical analysis of credit default swaps. International Review of Financial Analysis, 11(3): 297-309.

Toda, H. Y. \& Taku, Y. (1995). Statistical inference in Vector Autoregressions with possibly integrated processes. Journal of Econometrics, 66(1): 225-250.

Whetten, M., Adelson, M. \& Bemmelen M. V. (2004). Credit default swap primer, nomura fixed income research. https://tr.scribd.com/document/27781334/Credit-Default-Swap, (Accessed in 2017).

Yang, L., B. Morley, \& J. Hudson (2010). A study of the causal relationships between sovereign CDS spreads, Risk -Free interest rates and exchange Rates. Proceedings of the 8th INFINITI Conference on International Finance, Dublin, Ireland.

Zhang, G., Yau J. Hung-Gay, F. (2009). Do credit default swaps predict currency vaules? Applied Financial Economics: 1-44.

Zivot, E. \& Andrews, D. (1992). Further evidence on the great crash, the oil-price shock and the unit-root hypothesis. Journal of Business Economic Statistics, 10(3):.251-270. 